\title{
小澤圭次郎（醉園）の東京府立園芸学校に於ける 造園教育について
}

\section{Gardening Education by Keijiro Ozawa at Tokyo Metropolitan School of Horticulture}

\author{
小板橋二三男* 進士五十八** \\ Fumio KOITABASHI Isoya SINJI
}

\begin{abstract}
In April 1908, Tokyo Metropolitan School of Horticulture was established. This school was the first institution for horticulture education in Japan. Gardening education was officially included in its curriculum for the first time in Japan. Keijiro Ozawa was invited as a teacher of gardening by the second principle of this school, Taketaro Suzuki. His first lecture of gardening at this school began on June 21, 1911. We studied the gardening education by Ozawa at this school and found out many unknown documents and works of him. Making use of these findings, we focused on his carrier and works, his lecture, his textbooks used for gardening education, and his basic attitudes towards gardening and gardening education. In this period, he was the only man for the teacher of Japanese garden and gardening with enough carrier and works on gardening. He used three old books on Japanese gardening for the textbooks at this school. These books were Senzaihissyou(Sakuteiki), Sansuinarabininogatanozu and Musouryuukazanseisakunoki that he edited himself. Ozawa believed that Japanese gardening types consisted of just following three, Sansui, Hiraniwa and Karesansui. In June 1911, he also planned campus garden for this school. This garden plan consisted of three Japanese gardening types mentioned above.
\end{abstract}

Keywords: gardening education, Tokyo Metropolitan School of Horticulture, Keijiro OZAWA, books on gardening キーワード : 造園教育, 東京府立園芸学校, 小澤圭次郎, 園方書

\section{1.はじめに}

明治 38 年 (1905), 東京帝国大学農科大学教授横井時敬 （1860-1927）は，日本園芸会雑誌に論説「園藝學校設立の必要」 を発表している ${ }^{1)}$ 。欧州留学中（1899 年 5 月〜1900 年 11 月）に 各国園芸学校を視察した経験から, 園芸学校設立の必要性につい て次のように記している。「今日の園藝といふもの〉主とする所 は先づ第一に花卉, 次いで果樹蔬菜などの培養にあるかの如く思 はれるが, 庭園藝といふことも決して之を等閑にすることが出來 ぬ。一略一，顧みて我國を見れば園藝學校といふものは一つもな い。我が國の農學校では園藝の事を兼ね教ふることがヨーロッパ の學校よりは善く出來るに相違ないけれども, 是を以て滿足する ことは無論出來ない。一略一日本の園藝は全體に於て歐米に劣っ て居るといふことである。一略一そのうちで獨り庭園藝に至つて は却つて日本が優つて居ると考へる。一略一今日の國家が盡すべ きは眞善美に就いて我大和民族の特長を益々發揮せしめて海外に 誇るに在ると思ふ。而して, 予は庭園藝の如きはその特長の一で あるといふことを信ずるのである。是に於て予は益々園藝學校設 立の必要にして且つ急務なることを主張せねばならぬ。」横井は, 園芸作物栽培之, 欧米より優れている「庭園芸」(庭園)の教育の ために園芸学校の設立が必要だと主張しているのである。横井の 主張が, 後の園芸学校設立に直接結びついたかどうかは不明であ るが，少なくともその動機の一つとはなったものと推測できる。

明治 40 年代初頭に, 園芸の名を冠した我が国初の学校が, 2 校創立された。明治 41 年（1908）4 月開校の東京府立園芸学校, 翌明治 42 年（1909） 4 月開校の千葉県立園芸専門学校の 2 校で ある。また, 明治 42 年 (1909) 年, 大阪府立農学校に新たに園 芸科が設置される ${ }^{2)} 。 こ の 3$ 校に於いて初めて,「庭園」がその 学科過程 (教育課程) に位置づけられた。つまり我が国の農業教 育機関において, その教育課程に位置づけられた造園教育は，こ の二つの園芸学校及び大阪府立農学校園芸科の 3 校に於ける「庭 園」から始まったのである。
千葉県立園芸専門学校の設立時の教育課程には,「庭園」は設 置されていないが，翌明治 43 年（1910）の教育課程の見直しに より, 園芸関係学科目の一つとして「庭園論」が創設され， 3 学 年 1 学期, 毎週 3 時間履修と定められた ${ }^{3)}$ 。庭園論の講義は, 第 1 期生 3 学年対象に明治 44 年（1911）に開始され, 初代学校長 鏡保之介（1868-1931）が，開講から翌年 6 月 26 日朝鮮総督府勧 業模範場技師転任までの約 2 年間担当している。上原敬二 （1889-1981）は，鏡によるこの講義を，「全国の学校において高 下を問わず庭園の講義を行ったところはこの学校をもって最初と する。よその意義を指摘している ${ }^{4)}$ 。

一方, 東京府立園芸学校では, すでに創立時の教育課程に学科 目園芸の 3 学年 6 時間履修の教育内容（具体的には果樹, 蔬菜, 観賞植物, 庭園, 温室管理, 果菜調理) の一つとして明記されて いた ${ }^{5)}$ 。千葉県立園芸専門学校での学科目庭園論設置に先立つ 2 年前のことであった。したがって, 我が国の農業教育機関におい て, その教育課程に「庭園」が明記されたのは, 東京府立園芸学 校の教育課程を以て嗃矢とすることができる。

東京府立園芸学校に於いて教育課程通りに教育が実施されたと すれば，庭園の講義開始は，明治 43 年（1910）となる。同年 8 月, 宮澤文吾 $\left.{ }^{6}\right)$ が, 「植物, 病理, 地質, 花卉, 庭園及び実習」 担当教諭として, 赴任する。したがって, 2 学期から宮澤による 何らかの「庭園」の講義が行われたと推測できるが，これを裏付 ける資料は現存していない? 。後述するように，記録上明確なの は，小澤圭次郎（1862-1932 号醉園）が，明治 44 年（1911）か らこの講義を担当したことである。

千葉県立園芸専門学校の造園教育についは, 西村公宏の研究 ${ }^{8)}$ があるが, 東京府立園芸学校に於ける造園教育については, 小林 治人 ${ }^{9)}$ によって小澤圭次郎の造園教育について, わずかに紹介さ れているのみである。

本論文では，これまで殆ど知られていない東京府立園芸学校に 於ける小澤の造園教育について，新発掘の資料をもとに講師就任

\footnotetext{
${ }^{*} *$ 東京農業大学大学院農学研究科環境共生学専攻 ${ }^{* *}$ 東京農業大学地域環境科学部造園科学科
} 
の経緯, 庭園講義の実態, 講義に用いた園方書, さらに小澤の庭 園観，造園教育観について明らかにする。

\section{2. 小澤圭次郎の造園関係業績と東京府立園芸学校講師就任}

\section{（1）小澤圭次郎の経歴及び造園に関する業績}

小澤圭次郎は，天保 13 年（1842）4月 2 日桑名藩の医官小澤 長庵の次男として生まれ, 文久 2 年 (1862), 長兄の死に伴いそ の跡を継いで藩医となる。慶応 3 年 (1867), 藩命により桑名に 帰藩, 明治 3 年 (1870), 東京にもどる ${ }^{10)}$ 。この後, 明治 4 年 （1871）から，官職に就く。

今回, 新たに見いだした, 東京府立園芸学校講師就任にあたっ て東京府に提出された, 小澤自筆履歴書 $($ 表 -1 ) には, 官職経 歴が，詳細に記載されている。小澤の官職経歴は，明治 4 年 （1871）の海軍兵学寮出仕に始まる。翌 5 年文部省に転じ, 「字書 取調」となり, 明治 6 年 (1873) 4 月から, 東京師範学校勤務と なり, 同 8 年（1875） 5 月に同校学校長補, 教諭を経て, 明治 10 年（1877） 8 月には，同校訓導となる。明治 12 年（1879）3 月に 東京学士会院書記に転じ, 東京図書館一等書記兼東京教育博物館 詰, 東京図書館 - 東京教育博物館庶務掛兼図書掛を経て, 明治 19 年（1886） 3 月 29 日, 東京学士院書記辞職を最後に官職から 離れる。

この後, 造園研究に邁進, 「園林丵書」執筆のかたわら, 明治 23 年 (1890), 美術雑誌「国華」への「園苑源流考」連載を皮切 りに,「日本園芸会雑誌」,「園芸之友」,「建築工芸叢誌」に多くの 論説, 記事を執筆し, 単行本 2 冊, 執筆・編集している。これら 小澤の造園関係執筆業績を整理したものが表－2である。

また, 履歴書後半に見られるように, 多くの庭園・公園等の設

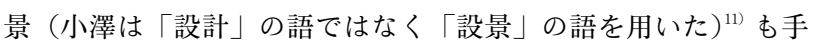
がけている。小澤は, まさに学と造園実務の両方を実践した造園 家であり, 東京府立園芸学校「庭園」講師としては, その経歴, 業績共に申し分のない, まさにうってつけの人物であったといえ よう。

小澤は, 自己の造園研究について「庭園に就て」の中で「㧋て 私は, 生來の造園道樂でありますが, 暴に官途に居し頃から, 餘 㗇に園事を心掛抢りて, 既に三十有餘年來, 和漢の造園の事に就 て, 一身を犠牲に供し, 百事を抛擲に付して, 今尚一大著述 園 林丵書と題名に從事し, 是非とも生前に竣功して, 身後に遺傳 すべき志願で, 編輯しつ〉あります」と語っている ${ }^{12)}$ 。この記述 から小澤の造園研究は, 官職にあった明治 10 年代からすでに始 まっていたことがわかる。筆者の見解によれば, 小澤が造園研究 に本格的に乗り出した時期は, 履歴書の記載から推測して, 明治 12 年 (1878) の東京師範学校から東京学士会院書記へ転じた頃 ではないかと推測できる。収入の大幅な減少（約三分の一）にも かかわらず東京学士会院書記へ転じているからである。

また, 小澤の庭園研究の動機について, 上原は, 「どうして庭 園研究に入ったかについて筆者の質問に答えたのは京都の名園の 美しさに魅せられたとのこと」 ${ }^{13)}$ と記している。

上記「庭園に就て」の引用文の中で注目すべきことは, 冒頭の 「造園道楽」の語に「にわつくりだうらく」とルビを付している ことである。このことから小澤は,「造園」の語を「造庭」ある いは「作庭」の意味で使用していることがわかる。また, 明治 23 年（1890）連載を開始した「園苑源流考」の中で, 小澤は「造園 ノ濫觴」(庭園の始まりの意) の語を使用し ${ }^{14}$, この後も本連載 の中で「造園」の語を多用している。つまり, 小澤は「造園」の 語を「庭園」,「造庭」,「作庭」の意味で, 使用していたのである。 これは，上原の「この時代抒よびこれ以前の造園家は日常対話の 際, 庭園とか, 庭とかという発言を行わず, それと全く同じ意味 で「造園」と称していたことは特に銘記しておきたい。」との記
述とも一致している ${ }^{15)}$ 。このことから，本論文の表題に「造園教 育」の語を用いたのは妥当性があるといえる。

なお，明治・大正期の著名な園芸学者，宮廷園芸技師であった 福羽逸人（1856-1921）は，小澤を「本邦造庭法ノ大家」と評価 し，世間に正しく理解されないことを嘆いて「一略一偶々本邦造 庭法ノ大家小澤圭次郎氏ノ如キ人アリ卜雖モ世人八氏ノ誠見卜技 倆卜ヨ玩味スルノ常識ナキカ為二往々氏ヨ歓迎セス実二痛歎ノ至 リナリ $\rfloor^{16)}$ と記している。また，東京府立園芸学校の卒業生磯村 春夫（大正 15 年（1926）卒）は，庭園視察での小澤の思い出を 「三年になると小沢先生引率の庭園視察があった。品川の岩崎邸 では, 豪壮な住居の前庭に家紋の輪違いを道に作ってあった。小 沢先生は案内しておられる当邸のご主人に対し, 自分の羽織の紋 を指さして「己の紋を他人に踏まれたらどんな気がする」と言わ れた。」記している ${ }^{17)}$ 。これらの記述から小澤圭次郎の人とな りを理解することができる。

\section{表－1 講師就任に当たり東京府へ提出の小澤圭次郎履歴書}

\begin{tabular}{lll}
\hline 履 & 歴 & 書 \\
本 & 籍 東京市本郷区駒込富士前町五拾番地 \\
族 & 籍 平民 \\
現住所 本籍二全シ
\end{tabular}
小澤 圭次郎 天保十三年四月三日生

担当学科名 庭園

年 月 日 明治 4 年11月14日 海軍兵学寮十三等出仕申付候事 任免 賞罰事故官衙

全 12 月 26 日 十二等出仕申付候事 海軍兵学寮出勤如故 全 全 5 年 4 月17日 兵学寮十二等出仕申付候事 海軍省 全 7 月28日 出仕差免候事 御用有之候二付滞京申付 全 候事

全 8 月 2 日 兵学寮十二等出仕申付候事

全 9 月15日 兵学寮十一等出仕申付候事

全 10月19日 依願出仕差免候事 全

全 11 月 5 日十一等出仕申付候事 字書取調申付候事 文部省

全 6 年 4 月 22 日 等出仕申付候事 編書課可相勤事 全

全 4 月25日 東京師範学校出勤可相勤事 全

全 7 年 9 月 9 日 任三等教諭

全12月3日 監事兼勤申付候事東京師範学校

全 8 年 4 月 27 日 当分師範学校長ノ心得 7 以于事務文部省

兼勤可事

全 5 月22日 東京師範学校長補ノ任

一ヶ月金六拾円交付候事中不二麿

全 10 年 8 月 31 日東京師範学校訓導ノ任 7 嘱シ文部省

一ヶ月金八拾円交付候事

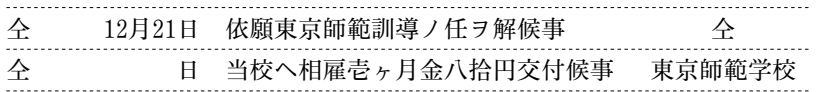

全 旦 事務兼教員可相勤事 文部省

全 12 月22日 依願雇相解候事

全 12 年 3 月 1 日 東京学士会院書記ノ任 7 嘱又東京学士会院 一ヶ年金三百円交付候事

全 13 年 3 月 23 日 一个年金六百円交付候事 全

全 14 年 4 月 20 日 御用掛申付候事 取扱判任二準シ文部省 月俸給金五十円交付候事

\begin{tabular}{|c|c|c|c|}
\hline " & " & 内記局可相勤事 & 全 \\
\hline 众 & 4 月 29 日 & 文部省御用掛被命候二付一ヶ年 & 众 \\
\hline
\end{tabular}

全 5 月31日 本院書記嘱託中為手当一ヶ年東京学士会院 


\begin{tabular}{|c|c|c|}
\hline & & 金二百四十円交 \\
\hline 소 & 10月24日 & 内記課勤務申付候事 \\
\hline 全 & 16年 12 月 10 日 & 任文部一等属 \\
\hline 全 & 18年 2 月 18 日 & 内記局詰申付候事 \\
\hline 企 & 6 月 4 日 & 任東京図書館一等書記 \\
\hline 소 & 旦 & 兼東京教育博物館詰申付候事 \\
\hline 全 & 9 月21日 & 庶務掛兼図書掛申付候事 \\
\hline 全 & 日 & 庶務掛兼図書掛申付候事 \\
\hline 全 & 19 年 3 月 29 日 & 非職申付 \\
\hline 全 & 4 月 3 日 & 依願東京学士会院書記解任 \\
\hline 全 & 4 月 7 日 & $\begin{array}{l}\text { 東京学士会院書記勤務中勉励候二付 } \\
\text { 為手当金五十円給与 }\end{array}$ \\
\hline 全 & 22 年 5 月 3 日 & $\begin{array}{l}\text { 非職満期ノ処在職満五年以上二付 } \\
\text { 月俸三ヶ月分給与 }\end{array}$ \\
\hline & 21年 7 月 & $\begin{array}{l}\text { 伊勢神苑会ノ聘二応シ山田二出張, 内宮外宮神苑新設 } \\
\text { 案図案並二解説及予算書 } \exists \text { 作製 }\end{array}$ \\
\hline & 22 年 3 月 & 両神苑築造二着手全九月落成又 \\
\hline & 30 年 6 月 & $\begin{array}{l}\text { 香川県知事徳久恒徳ノ嘱二応シテ栗林公園保護論 } \text { 著 } \\
\text { 作又 }\end{array}$ \\
\hline & 26 年10月 & 日本園芸会ノ依託 兼テ公園論一冊 ヨ著作ス \\
\hline & 36年 1 月 & $\begin{array}{l}\text { 群馬県高崎市役所ノ聘二応シ全公園改修ノ設景図案並 } \\
\text { 其解説及予算書作成ス }\end{array}$ \\
\hline & 36 年 3 月 & $\begin{array}{l}\text { 東京帝国博物館長股野玩ノ依嘱ヨ承ケ上野公園内一部 } \\
\text { ノ新修設計図案並二其解説書ᄏ調製セリリ }\end{array}$ \\
\hline & 40 年 8 月 & $\begin{array}{l}\text { 大阪市長山下重威ノ聘二応シ天王寺公園ノ設計図案其 } \\
\text { 解説及予算書 } \ni \text { 調製 } ᄌ\end{array}$ \\
\hline & 42年 1 月 & 天王寺公園築造二着手シ完成セリ \\
\hline & 42 年 4 月 & $\begin{array}{l}\text { 農商務省内日英博覧会事務局二召喚セラレ全博覧会場 } \\
\text { 内二築造スル処ノ純粋ナル本庭園設計ノ件嘱託セラ } \\
\text { レ設景図案並二其解説及予算書ヨ調製ス其他公私ノ依 } \\
\text { 託ニヨリ庭園築造二従事完成セシモノ多シ }\end{array}$ \\
\hline
\end{tabular}

・小澤が東京府に提出した自筆の履歴書を横書きに改めた。年月日欄の数 字は, 算用数字とした。この記述からわかるように, 小澤は, 官職の経歴 については，交付された辞令の文面をそのまま記載している。明治 44 年, 第 1 類 - 文書類纂 - 学事第 9 類 - 府立学校職員第 3 巻収蔵, 東京都公文書 館蔵より作成。

\section{表－２小澤圭次郎造園関係執筆業績一覧}

国華（明治 22 年 10 月創刊）

-「園苑源流考」第 5-181 号, 明治 23 年（1890）-同 38 年（1906）, 都合 141 回連載. ( 除く第 $10 ， 68 ， 79 ， 94 ， 96 ， 135 ， 136 ， 141 ， 143-147$, $149-152,154,155,157,159,161-164,166,168,169,171,173-1$ 77, 180 号)

日本園芸会雑誌（明治 22 年 4 月創刊）

•「公園論」第 $47-51$ 号, 明治 26 年・ 27 年 (1894)

・「大久保村踟躅花を覧るの記」第 56 号，明治 27 年（1894）

・「霞加関御園生の纴丹花拝見の記」第 56 号，明治 27 年（1894）

-「奈良公園改修説并帝國奈良博物館苑池創造説」第 63 - 64 号, 明治 28 年 $(1895)$

-「奈良公園改修説并帝國奈良博物館苑池創造説の絵圖に付き質問回答 の顛末」第 66 号, 明治 28 年 (1895)

•「春秋園池記ノ事」第 75 号, 明治 29 年 (1896)

・「海賊橋東詰ノ牧野候屋敷の園池」第 76 号, 明治 29 年（1896）

・「名園狳觀」第 77-156 号, 明治 29 年（1895）-38 年（1905） (除く 98，104，106,107,111，114，116，117，119，121，154号)

•「木戸侯爵の庭園」第 89 号, 明治 30 年 (1897)

•「香川縣琴弾公園ノ設景」第 94 号, 明治 33 年 (1900)
・「七松園」第 148 号, 明治 37 年 (1904)

(明治 38 年 7 月第 158 号より「日本園芸雑誌」と改題)

・「消夏清趣篇」第 159 号, 明治 38 年 (1905)

•「園林茶談」第 163 号, 明治 39 年（1906）

•「日本古代の造園書に就て」第 225 号，明治 44 年（1911）

・「庭園に就て」第 234 号-第 236, 明治 45 年 (1912)

園芸之友 (明治 38 年 5 月創刊)

・「庭園称謂の弁別」第 1 年第 1 号, 明治 38 年 (1905)

•「庭園石燈籠並其建設場所に就きて」第 2 年 1 号，明治 39 年（1906）

・「趺石小話」第 2 年 2 号，明治 39 年 (1906)

・「京都御所林泉図解」第 2 年 3 号, 明治 39 年 (1906)

・「庭園上の桜花観」第 2 年 4 号, 明治 39 年 (1906)

・「針前の制作」第 2 年 5 号, 明治 39 年 (1906)

・「う急ごみ名称と事実」第 2 年 6 号, 明治 39 年 (1906)

・「造園方の真行草に就きて」第 2 年 12 号, 明治 39 年 (1906)

・「庭園称謂の弁別に就きて」第 4 年 5 号, 明治 41 年 (1908)

-「大阪天王寺公園の興造」第 6 年 $1 \cdot 2 \cdot 3$ 号, 明治 43 年 (1910)

・「日英博覧会の日本風林泉」第 6 年 11-12 号, 明治 43 年 (1910)

• 「平安京搢紳家の庭園造方」第 7 年 $1 \cdot 2 \cdot 4$ 号, 明治 44 年 (1911)

•「平安京㩖紳家の園池に使用する龍頭鵒首船の記並に其典故」第 8 年 7 号，明治 45 年 (1912)

・「曲水宴遊の源流紀述」第 12 年 1-4, 9-12，第 13 年 6 号，大正 5 年 （1916）-大正 6 年 (1917)

建築工芸叢誌（明治 45 年 2 月創刊）

•「大名の庭園」明治 45 年（1912）第 1 冊

・「後楽園源流略記」明治 45 年 (1912) 第 2 冊

•「庭園源流略志」明治 45 年（1912）第 3 冊-大正 3 年（1914）第 24 冊

著書

-「明治庭園記」：明治園芸史 第 6 編：日本園芸研究会, 大正 4 年 (1915)

-「山水並野形圖 古傳園方書 尺素往来跋抄」小澤編，自費出版，大正 15 年 $(1926)$

・雑誌掲載の論説・記事は, 雑誌毎に提載年の早いむのから順番に「タイ トル」, 掲載巻号数, 掲載年の順に記載し，また連載については，煩雑さ を避けてまとめて掲載した。

\section{（2）小澤圭次郎の東京府立園芸学校講師就任}

先の「庭園に就て」の中で，小澤（写真－1）は，明治 44 年 （1911）5 月に東京府立園芸学校長鈴木武太郎（写真－2，1869没年不詳 $)^{18)}$ の依頼をうけ，6 月から当校生徒に講義をしている と記している ${ }^{19)}$ 。

東京府立園芸学校に於いて，小澤が講義を行うに到る具体的経

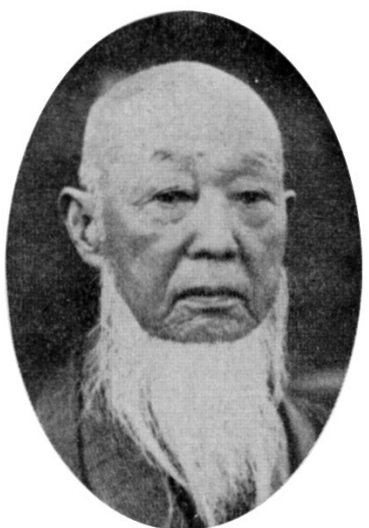

写真－1 小澤圭次郎肖像

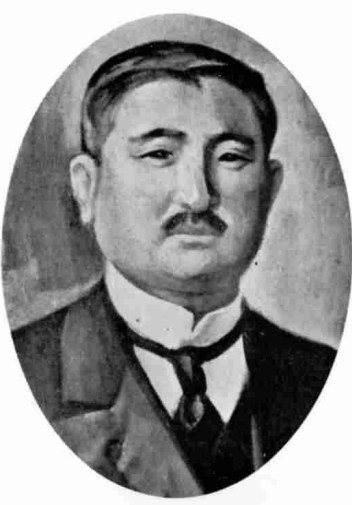

写真－ 2 鈴木武太郎肖像
東京都立園芸高等学校同空会編（1978）：東園の七十年：東京都立園芸高 等校同空会, 34p.，口絵） 
緯は, 今日まで知られていない。この経緯を知る手がかりは, 唯 一, 小澤の日記 (四十四年日記, 東京都立園芸高等学校蔵) の記 述のみである。（表－3）この記述から, 小澤の府立園芸学校講 師就任の具体的経緯を明らかにすると，次のようになる。

小澤と当校の関係は，鈴木校長が，小澤宅を明治 44 年（1911） 4 月 25 日に訪問したことに始まる。この最初の訪問の目的は, 当校創立記念日（明治 44 年 4 月 27 日）及び日本園芸会夏期講習 会での講演依頼であった ${ }^{20)}$ 。鈴木は，再び 5 月 18，19，20 日の 三日連続して, 小澤宅を訪問している。この間の訪問により小澤 の講師就任の受諾を得ている。5 月 18 日午后, 教諭宮澤文吾を 伴い小澤宅を訪問, 府立園芸学校の「日本庭園模範園」設景を打 診する。翌 19 日, 設景を正式に依頼, 小澤はこれを, 設景料 2 百円, 設景期間 2 週間で受諾している。更にこの日, 新たに, 生 徒一の庭園講義を，一年間 40 時間担当するよう打診している。 翌 20 日夜, 模範園の予算案作成を打診, 前日打診の講義につい て, 小澤は, 毎月 1 回 2 時間ずつ年間 24 時間, 年俸百円で受諾 している。小澤の受諾を承けて, 鈴木は, 東京府に上申書 ${ }^{21)}$ 提出，この上申書にもとづき，東京府は，明治 44 年（1911） 5 月 31 日付授業嘱託（講師）辞令を小澤に交付している。

鈴木は, 府立園芸学校開校後間もない明治 42 年に校長に就任 している。前校長熊谷八十三 ${ }^{22}$ の計画を引き継ぎ, 施設設備の充 実に努め, 明治 43 年（1910）には，一部を除きほぼこの整備を 終え，また，当校の教育に相応しい教員の採用にも努めていた。 前述のように, 鈴木は, 明治 43 年（1910）8月に，庭園を含む 担当教諭として宮澤の採用を果たしている。しかし宮澤の専門は, 観賞園芸（花卉）で, 庭園の専門ではなかった。したがって, こ の時期「庭園」担当に相応しい人材を未だ得ることが出来ない情 況にあった。

鈴木は, 創立記念日講演の内容として小澤に「庭園談」を要請 している。当然のことながら,この講演内容を小澤に求めた際に, 府立園芸学校での庭園教育の情況を話題にしたに違いない。小澤 との初対面から, 小澤に庭園講義講師就任の打診までに, 約一月 近くの時間を要している。これは, 小澤との対談を通じて, 庭園 講義を小澤に依頼しょうとする考えが，鈴木の中で固まるまでに 時間を要したためであると推測できる。

なお, 当校での小澤の講義回数について, かつての教諭宮地常 助 ${ }^{23)}$ は, 「週一回ずつ」と記しているが24), 5 月 20 の日記の記述 から明らかなように, 正確には, 月 1 回 2 時間ずつ一年間合計 24 時間の誤りである ${ }^{25)}$ 。

\section{表－３小澤日記にみる府立園芸学校講師就任の経緯}

年月日 日記記述

明治44年 4 月 25 日 東京府技師，東京府立園芸学校長鈴木武太郎来面又, 二ヶノ願有卜云フ, 明後廿七日朝, 同校創立記念会式 ヨ行フ, 其後にて生徒 集メテ一場の庭園談 談セン コトヨ乞フ, 諾レ之, 八月中旬夏期講習日本園芸会に て庭園談ヨ乞フ，諾レ之,

同年 5 月 18 日 后三半, 鈴木武太郎, 宮澤文吾両人来話, 日本庭園模 範園 校内二設景二付依頼有リ, 只本日中二来月度, 預算二組込ノ事ヨ云フ, 問答マテ,

同年 5 月 19 日 鈴木校長尋来云, 模範苑池設景 $コ$ 托ス卜, 二百円二テ 二週間出来 $ᄏ$ 約ス, 又学生二講義の事一学年四十時間 也，此ヨ以テナを教授の事話アリ，考察相応ルコト 約又,

同年 5 月 20 日 夜, 鈴木来云, 設景預算経ンコト $\ni$ 乞, 更二其報酬卅 円位出サジバ, 雖、頼ノコト申ス, 半諾ス, 又我講話 八, 一学年二廿四時間, 一月一回二時間なるにて, 報
酬百円ニテ我之ヨ承ス。

同年 6 月 14 日 八過, 鈴木校長ヨリ一封来, 前辞令手続違二付取替, 東京府ヨリ直接ノ嘱托也，返事，古写前栽秘抄一冊郵 送又,

- 明治 44 年小澤日記（東京都立園芸高等学校蔵）より講師就任の経緯に 関する記述部分のみ抽出。

\begin{tabular}{|c|c|c|c|c|c|c|c|c|}
\hline 科 & $\begin{array}{l:llll}\text { 目 } & \text { 第 } & 1 & \text { 学 } & \text { 年 }\end{array}$ & 时数: & 第 & 2 学 & 年 & 溡数: & 年 & 洔数 \\
\hline 終 & 人倫道徳ノ要旨 & 1 & 同 & & 左 & 1 & 左 & 1 \\
\hline 国 & 講 読, 作 文 & 3 & 同 & & 左 & 3 & 左 & 3 \\
\hline 英 & $\begin{array}{l}\text { 語 読方, 訳解, 文 } \\
\text { 法, 書取 }\end{array}$ & 3 & 同 & & 左 & \begin{tabular}{|l:l}
3 &
\end{tabular} & 左: & 3 \\
\hline 数 & 学 算術, 代数, 幾何 & 4 & & 数, & 何 & 3 & & \\
\hline 図 & 自在画, 用器画 & 2 & 同 & & 左 & 1 & & \\
\hline 体 & $\begin{array}{l}\text { 操 普 通 体 操 } \\
\text { 兵式体 操 }\end{array}$ & 2 & 同 & & 左 & $2:$ & 左 & 2 \\
\hline 物理及気象 & 象:物理及気象 & 3 & 気 & & 象 & 1 & & \\
\hline 化 学 & 学 無機及有機 & 3 & 同 & & 左 & 2 & & \\
\hline $\begin{array}{l}\text { 博物及 } \\
\text { 人身生理 }\end{array}$ & $\begin{array}{l:ll}\text { 及 } & \text { 動物 } & \text { 及 } \\
\text { 理 } & \text { 人身生 理 }\end{array}$ & 2 & & & & & & \\
\hline 植 & 物 植 物 & 2 & & & & & & \\
\hline $\begin{array}{ll} & \text { 鉱物, 岩石 } \\
\text { 劤 地 質 }\end{array}$ & $\begin{array}{l:l}\text { 石 } & \text { 鉱物, 岩石 } \\
\text { 質 地 }\end{array}$ & 1 & & & & & & \\
\hline 病害 虫 & & & & 害 & 虫 & 3 & & \\
\hline $\begin{array}{l}\text { 植物栄養土 } \\
\text { 壤及肥 料 }\end{array}$ & & & & & & & 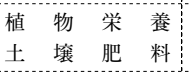 & 3 \\
\hline $\begin{array}{lll}\text { 農 } & \text { 業 } 土 \text { 木 } \\
\text { 及 } & \text { 農 }\end{array}$ & & & & & & & $\begin{array}{ccc}\text { 農 } & \text { 業 } & \text { 木 } \\
\text { 及 } & \text { 農 } & \text { 具 }\end{array}$ & 1 \\
\hline 作正物 & 物 各 & 2 & & 論及通 & 論 & 2 & & \\
\hline $\begin{array}{l}\text { 園 } \text { 芸 通 } \\
\text { 及 }\end{array}$ & & & & $\begin{array}{c}\text { 芸 通 } \\
\text { 果 }\end{array}$ & $\begin{array}{l}\text { 論 } \\
\text { 樹 }\end{array}$ & 2 & 樹 & 2 \\
\hline 蔬 & & & 蔬 & & 菜 & 2 & 菜 & 2 \\
\hline 観 賞 園 芸 & & & & 賞 植 & & 2 & $\begin{array}{l}\text { 観賞植物, 温室: } \\
\text { 管 理 庭 園 }\end{array}$ & 2 \\
\hline $\begin{array}{l}\text { 農産製造及 } \\
\text { 菜調理 }\end{array}$ & & & & & & & $\begin{array}{l}\text { 農産製造 及 } \\
\text { 菜調 }\end{array}$ & 2 \\
\hline 畜産 & 産 & & & & & & 音峷 & 2 \\
\hline 農 業 簿 記 & & & & 業 簿 & 記 & 1 & & \\
\hline 経済及法規 & & & & & & & $\begin{array}{l}\text { 経済学原論, 農業: } \\
\text { 経済, 農業法規 }\end{array}$ & 3 \\
\hline 合 & 計 & 28 & & & & 28 & & 26 \\
\hline 実 & $\begin{array}{l}\text { 習動植物 実験 } \\
\text { 围場実習 }\end{array}$ & & & $\begin{array}{l}\text { 植 物 実 } \\
\text { 場 } \\
\text { 実 } \\
\text { 室 } \\
\text { 荟 } \\
\text { 実 } \\
\text { 場 } \\
\text { 実 }\end{array}$ & $\begin{array}{l}\text { 験 } \\
\text { 習 } \\
\text { 習 } \\
\text { 習 } \\
\text { 験 }\end{array}$ & & 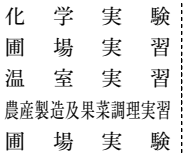 & \\
\hline
\end{tabular}

•本表は，明治 44 年（1911）3 月 16 日制定の「東京府立園藝学校學則」 第 9 条掲載の表を横組に改めた。数字は，毎週教授時数。(警視庁東京府 公報, 第 1683 号, 東京府令第 26 号明治 44 年（1911） 3 月 16 日）

\section{3. 小澤圭次郎の庭園講義}

（1）東京府立園芸学校の教育課程に於ける「庭園」の位置づけ

前述のように，鈴木校長の招聘により，小澤は明治 44 年 （1911）府立園芸学校の庭園講師に就任する。小澤が講師として 担当することとなった庭園の教育課程上の位置づけを概観すると, 次のようになる。

創立時に時の教育課程上での庭園の位置づけは, 3 年生履修の 学科目「園芸」の教育内容の一つであった。明治 44 年 (1911） 3 月の学則変更に伴い, その教育課程の変更がなされ，学科目「園 芸」は, 「園芸通論及果樹」,「蔬菜」,「観賞園芸」の 3 学科目に 分科された。つまり創立時教育課程において学科目「園芸」の教 育内容として掲げられていた， 2 年生履修の「通論，果樹」，3 年 履修の「果樹, 蔬菜, 観賞植物, 庭園, 温室管理, 果菜調理」を, それぞれ新たに学科目として独立させたのである。この改正によ 
り,「庭園」は, 学科目「観賞園芸」の 3 年生 2 時間履修の教育 内容, 具体的には観賞植物, 温室管理, 庭園の一つとして位置づ けられ, 果菜調理については, 学科目「農産製造」に含ませ学科 目「農産製造及果菜調理」に変更している。(表一 4 )

\section{（2）東京府立園芸学校に於ける小澤の庭園講義開始}

前述のように小澤の府立園芸学校の庭園講師就任は, 東京府の 辞令交付日の, 明治 44 年（1911）5月 31 日であった。この講義 開始の具体的日時については, 小澤日記（四十四年日記, 東京都 立園芸校高等学校蔵）の記述から知ることが出来る。明治 44 年 （1911）6月 21 日（水）の項に, 「廿一日 陰, 四時起六時出, 本 朝ヨリ無事出校, 九時ヨリ十一時迄講堂二テ前栽秘抄十枚斗話説 ス」と記述しているからである。小澤がこの日に講義を開始する に到った経緯は，鈴木の小澤宛書簡 ${ }^{26)}$ から知ることができる。明 治 44 年 6 月 13 日付小澤宛書簡で, 学校の都合上, 小澤の講義時 間を水曜日の午前 9 時から 11 時までの 2 時間と定め, 小澤の講 義開始の日を 6 月 21 日か 28 日両日のどちらがよいか, その都合 を問い合わせている。翌 14 日，小澤はこの書簡を受け取ると折 り返し返書と謄写印刷のための原稿として「古写前栽秘抄」 1 冊 を鈴木宛に郵送している。つまり, 鈴木がその書簡で指定した上 記二日の内, 6 月 21 日（水）に講義開始となったのである。小 澤, 齢 69 歳のことであった。

\section{（３）小澤圭次郎による庭園講義の内容}

小澤は, 東京府立園芸学校での講義の内容について講演記録 「庭園に就て」の中で「日本造園の方書を, 學生諸君に向て, 講 義致し居ります,」と記している ${ }^{27}$ 。この記述に明らかなように 小澤の「庭園」講義は, 「日本造園の方書」についての講義であっ た。この「日本造園の方書」とは, 具体的何を指すのか, またど の程度の時間をこれの解説に費やしたのか, これを知る手がかり は, 小澤の日記の記述のみである。小澤の明治 44,45 年日記 （東京都立園芸高等学校蔵）の記述から, 初年度 (明治 44 年度) の小澤の講義内容とその時間をまとめると次のようになる。

前述のように, 小澤はその講義を, 明治 44 年（1911）6月 21 日の「前栽秘抄」の解説から始めている。また，9月 21 日には, 翌月からの講義に備えて, 増圓撰「最古園方書」 1 冊を謄写版印 刷の原稿として府立園芸学校に提出している。12月 6 日には, この園方書（「増圓哲書」）の講義を終了している。10月 11 日か ら 12 月 6 日までの 4 回にわたって, この「最古園方書」を教材 に講義を行ったことになる。更に, 11 月 8 日, 府立園芸学校へ 赴き, $\underline{3}$ 学期の講義に備え, 「園書無名巻」を謄写版印刷の原稿 として提出している。翌年明治 45 年（1912） 1 月 17 日から 3 月 6 日までの 4 回にわたって,「園書無名巻」の講義を行い, 最後 に伝授系図について講義を行っている ${ }^{28)}$ 。

以上のことから, 小澤による初年度の庭園講義は, 合計 12 回 行われ, 初めの 4 回 (8 時間) を「前栽秘抄」の解説に, 次ぎの 4 回 (8 時間) を増圓撰「最古園方書」の解説に, 最後の 4 回 (8 時間）を,「園書無名巻」の解説にそれぞれ充て, 講義の最後に 「伝授系図」の解説をして, 初年度一年間の講義を全て終了した ことになる。この講義方法は, この講義開始以来, 昭和 6 年 （1931）3 月の講師退任まで, 変わることはなかった。

\section{（4）小澤の庭園講義に対する基本的態度}

前述の通り, 東京府立園芸学校に於ける小澤の庭園講義は, 「日本造園の方書」を教材に行われた。小澤が庭園講義の教材に 「日本造園の方書」を用いた理由は, 講師就任に先立つ明治 44 年 （1911）4月 27 日, 府立園芸学校創立記念日の小澤の講演記録 「日本古代の造園書に就て $\rfloor^{29)}$ の中で明らかにされている。本講演 記録冒頭部分で, 明治維新後に刊行された造園書について, この 著者が, 古代園方書の把握をしていないため, その内容が取るに 足らないものだと批判し, 更に, 江戸時代に刊行された「築山庭
造傳」「築山庭造傳後編」三巻,「石組園生八重垣傳」二巻につ いて, これら刊行書に説かれている庭造法の「真行草」について, これは書体の区別であり庭造法には全く関係がないと退け, 園石 の形状の名称として用いられている「律呂」についても，これは 声音上の題目で, 造庭には全く関係のないものであるとし退けて いる。つまり，これらは，古代園方書にはない，単なる僻説すぎ ないと断じているのである。またこの僻説の出所について, 今日 嵯峨流古法秘伝之書と呼ばれる応永年間の奥書がある造園書に, 初めて出現したもので, 築山庭造伝以下, 不学無識の著者が, こ れらの僻説を鵜吞みにして無批判にその著書に採り入れたもので あると語り, 本講演の最後を「新刊の造園書を讀で, 其得失を辨 知せん之欲するには, 古代園方書の渉獵を終らざれば，できませ ん譯で有ます。」と結んでいる。

明治維新後出版の造園書は, 江戸時代刊行園方書（「築山庭造 伝」,「筑山庭造伝後編」,「石組園生八重垣伝」）に範を取ってい るが，江戸時代刊行園方書以前の古代園方書の内容を把握してい ないため取るに足らない内容となっている。そこで新刊の造園書 の内容の真偽を判断するために, また, 僻説の出所を知るために も, 古代園方書の内容を知る必要があると主張しているのである。 つまり, 物事の真偽を判断するには, その原点を知らなければな らないと主張しているのである。まさにこの主張こそ, 府立園芸 学校に於ける庭園講義に対する，小澤の基本的考えであった。

なお，小澤は「造園の方法を記した書」の名称として, 雑誌 「国華」連載の「園苑源流考」（明治 26 年 (1893)) の中では, 「造園ノ方書」,「園方書」を用い ${ }^{300}$ ，上記「日本古代の造園書に 就て」(明治 44 年 (1911)) に於いては, 「造園書」,「園方書」を 用い, 『明治園芸史』掲載の「明治庭園記」(大正 4 年 (1915) ) では,「造園方法書」，「園方書」の名称をそれぞれ用いている ${ }^{31}$ 。 つまり，小澤は，「造園の方法を記した書」の総称として，これ ら各名称を用い, 江戸時代刊行以前の園方書を他の園方書と区別 して, 特に「古代園方書」または「古伝園方書」と称していたの である。

\section{4. 小澤圭次郎が庭園講義教材に用いた園方書}

前述のように小澤が東京府立園芸学校で講義の教材として用い た園方書は, 「前栽秘抄」, 増圓撰「最古園方書」, 「園書無名巻」 の 3 冊である。これら園方書は全て, 小澤が私財を投じて自ら収 集した資料と, 他家所蔵の写本とを校合・校訂して, 冊子として 作成したものである。

\section{(1) 前栽秘抄 一名作庭記}

小澤日記, 明治 44 年 6 月 14 日の記述にある, 謄写版印刷の原 稿として東京府立園芸学校に郵送した「古写前栽秘抄」とは, 現 在東京都立中央図書館加賀文庫に収蔵されている，小澤手写「前 栽秘抄 一名作庭記」(38 丁, 写真 -3 , 今日一般に作庭記と呼 ばれる)である。

本冊子跋によれば，本冊子作成のために校合・校訂に用いたも のは, 自蔵の刊本作庭記 (群書類従 362 遊戯部所収), 同古写本 三種と，他家から借覧した山水抄三巻とである。中でも，山水抄 三巻は，本冊子作成に大きな役割を担っていた。

小澤が明治 25 年（1892）2 月に作成した冊子「山水抄 上中下 三巻」 ${ }^{322}$ の序には，この山水抄を手にした経緯とその校訂の経緯 並に本冊子との関係を記している。この序の記述と, 小澤の明治 25 年日記 (東京都立園芸高等学校蔵) の記述から, これらの経 緯をまとめると, 次のようになる。

山水抄三巻は, 東京帝国博物館が, 明治 25 年（1892） 1 月に 小筆家から借りだし, 同館理事山高信離（1842-1907, この時期, 帝国博物館館長を経て同館理事の職にあった)，本書の鑑定を小 澤に依頼するため，川崎千乕（1835-1902，明治期の画家，この 
時期帝国博物館御用掛）に命じて，明治 25 年（1888） 1 月 27 日， 小澤宅に届けさせたものである。この，2 日後 1 月 30 日には， 小澤は, この写本を終え校訂加朱に着手, 翌 31 日にはこの山水 抄三巻と, 作庭記の著者についての弁妄を完成させ, 翌月 2 月 1 日には，鑑定結果を添え，川崎に返却している。翌 2 月 2 日には, 跋を記し，2月 4 日に，山水抄三巻校訂を終了している ${ }^{33)}$ 。

「前栽秘抄 一名作庭記」跋の記述によれば, 本冊子は, 先の 山水抄三巻の校訂終了後, この山水抄三巻と作庭記とを対照考校 し, 作庭記の誤字脱言を山水抄三巻によって校訂し, 明治 25 年 5 月に本冊子「前栽秘抄 一名作庭記」の作成を終えたことになる。 また，山水抄三巻との対照考校の過程で，作庭記の作者が，後 京極摂政良経（藤原良経 1169-1206）ではなく，伏見修理大夫橘 朝臣（橘俊綱, 1028-1094）であることを山水抄下巻末尾の記述 から知ることが出来たとして, 本冊子「前栽秘抄 一名作庭記」 跋に次のように記している。「予此書熟玩の後に, 決然此書は, 後京極摂政良経公の著作に非ずと断言せり, 然らば, 此書は何人 の著作に屬するもとかと, 云ふに, 此は伏見修理大夫橘朝臣が, 園事見聞日記なる事を，山水抄柴需の末尾に拎いて，知得したり」 作庭記の著者を, 橘俊綱としたのは, 小澤をもって䠢矢とする ことができる。

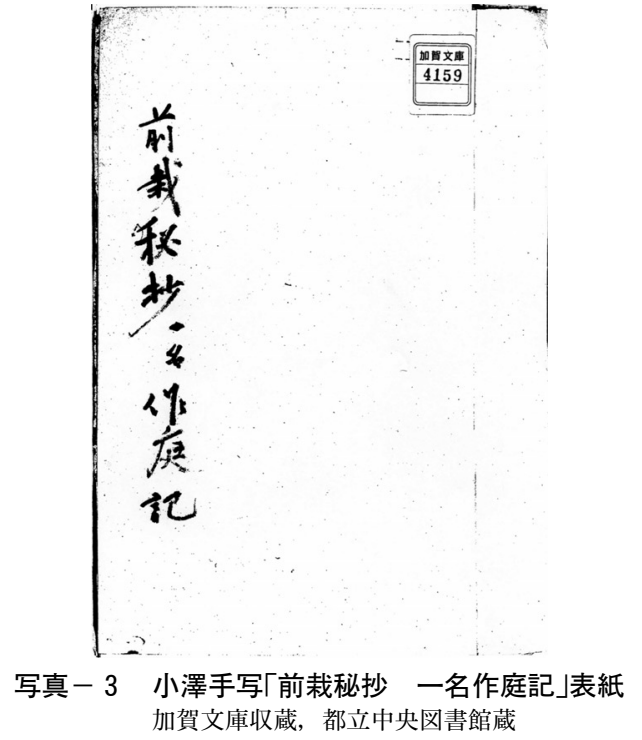

（2）増圓撰 最古園方書（山水并野形図）

明治 44 年 (1911) 9 月 21 日, 謄写印刷原稿として府立園芸学 校に提出した冊子が，東京都立中央図書館加賀文庫収蔵の「元巻 外題無名巻軸也 増圓僧正撰 皇國最古園方書 全」(44丁, 写真4) である。本巻は巻首に「山水并野形図 増圓撰」と記されて いることから後に「山水并野形図」と呼ばれるようになる。

本冊子作成のために小澤が校合・校訂に用いたものは, 自蔵の 模巻一巻とその元巻となる前田侯爵家蔵の信嚴法印（1420-1504） 自筆一巻とである。本冊子跋には, 本巻を作庭記に先立つ我が国 最古の園方書と決定するに到った理由を，次のように記している。 「按スルニ, 増圓僧正撰術ノ園方書八, 皇國二拎テ, 造園ノ方法 ヨ論説シタル嚆矢卜謂フ可キ者ナリ, 巻中記載ノ山水圖, 野筋様 ᄏ始入, 池沼ノ淺深, 魚鳥ノ放養, 草木ノ種藝培殖, 并二立石・ 臥石ノ名目形状, 曲山・曲木, 曲河・曲石等八, 未夕作庭記,

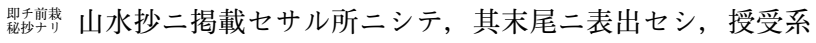
統ヨ一讀スレバ, 則チ复二前古ノ著書タルコト, 論辨ヨ俟タズシ テ明白ナリ」上記理由から，本冊子の表題を「皇国最古園方書」 としているのである。

本冊子の序には, 前田侯爵家蔵の元巻を借覧にするに到った経 緯, 及び自蔵巻がこの副本 (模巻) であると確認した経緯につい

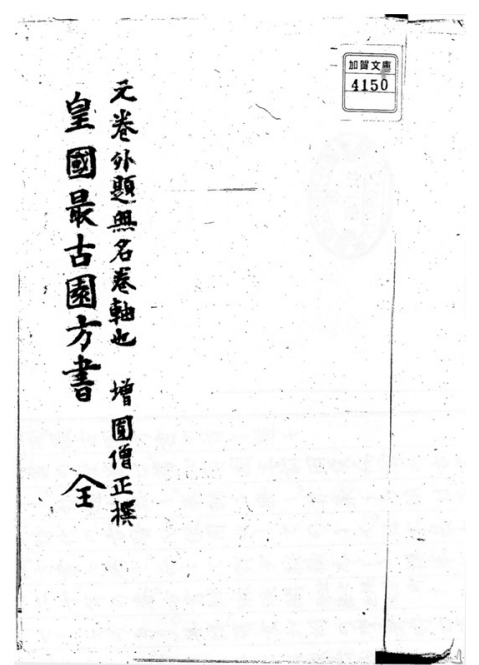

写真 -4 「元巻外題無名巻軸也 増圓僧正撰 皇國最古園方書全」 表紙 加賀文庫収蔵, 都立中央図書館蔵

て記している。本冊子の序及び小澤日記の記述 ${ }^{34)}$ から，「増圓僧 正撰 皇國最古園方書 全」の校合の経緯及びその時期をまとめる と次のようになる。

明治 25 年（1892）1月 29 日, 小澤は, 前田侯爵記家の友人野 口之布（1830-1898）に「京後京極殿作庭記二巻」の借覧依頼を する。この依頼は，作庭記が紛失して見つからず果たせなかった が, 代わりに増圓撰「古文書」一巻が, 野口によって探し出され, これを見てはどうかとの誘いを受ける，2月 8 日，前田侯爵邸内 野口宅にて, 前田侯爵家蔵一巻を借覧し, 自蔵巻は前田侯爵家で 作成された副本二巻の内の一つ, すなわち模巻であると確認, 翌 月 3 月 14 日再度, 野口宅にて自蔵模巻との校合を終了している。 この後, 小澤は, 明治 26 年 (1893), この全文を, 国華に連載中 の「園苑源流考 」35) に，初めて掲載している。

国華掲載の翌年，明治 27 年（1894）4月 14 日の「向島大火」 によって自蔵模巻を焼失する。焼失の翌年明治 28 年（1895）に, 逆に国華に掲載した全文を写し取り，本冊子を作成している。こ の自蔵模巻焼失から本冊子作成までの経緯を，本冊子序に「二十 七年甲午，四月十五日，向島大火の時に我家は延焼して，此副本 屯鳥有となりたり, 然るに, 先 是, 國華第四十八號廿六年九月 刊行以下, 第四十九號, 第五十號に, 此書を抄して, 分載し置き たるゆ急に，更に是を國華より寫取りて，一冊子と為し，之を讀 む者の便益に資するが為めに，句讀を點し，返點を施し，尚且行 間に漢字義譯を挿記して, 以て皇國最古園方書と題簽すと云爾, 明治二十有八年三月, 醉園子, 本郷僑, 駒込, 神明町三百四十七 番地僑寓, 天雀堂西空の下に識す」と記している。この序末尾の 記述から本冊子は, 明治 28 年（1895）3 月に作成されたことに なる。

しかし，小澤日記の明治 44 年（1911）9月 20 日には「最古園 方書, 序跋成, 浄写ス」との記述があることから, 明治 28 年 （1895）3 月に作成した冊子に, 府立園芸学校の講義教材とする ため, 新たに序・跋を附して完成したものが本冊子となる。つま り, 本冊子が最終的に完成したのは, 上記序末尾記載の日ではな く, 明治 44 年（1911） 9 月 20 日となる。したがって, 本冊子の 序, 跋も実際に書かれたのは, 序跋末尾記載の時期ではなく, 明 治 44 年（1911）9 月 20 日となる。

また, 本冊子跋末尾に「明治二十六年, 二月中浣, 墨江東畔, 受地坊, 秋葉祠南ノ淡静盧南軒二識又, 醉園居士小澤圭」と記し ていることから，焼失前に本巻の校訂を終えた時期は，明治 26 年（1893）2月中浣（中旬）であったことがわかる。 


\section{（３）園書無名巻（嵯峨流古法秘伝之書）}

明治 44 年（1911）11月 28 日, 謄写印刷の原稿として東京府 立園芸学校に提出した冊子が, 東京都立中央図書館加賀文庫収蔵 の「夢窗流 假山制作之規 全」(15丁, 今日一般に嵯峨流古法秘 伝之書之呼ばれる，写真－5）である。

本冊子末尾には, 日付の異なる跋が，2 種類付されている。明 治 28 年（1895）春の咙と, 明治 44 年（1911）11月の跋である。 小澤は，本冊子を日記に「園書無名巻」と記述しているが，その 理由は, 明治 28 年（1895）春の咙に,「斯篇八，假山制作之規, 夢空流。卜云ヘル題名ヨ掲記スレドモ, 其根元 7 捜索スレバ, 全 ク元巻八, 無名ノ巻物ニシテ, 作者ノ姓名モ詳ナラザル者ナリ」 と記していることからわかる。

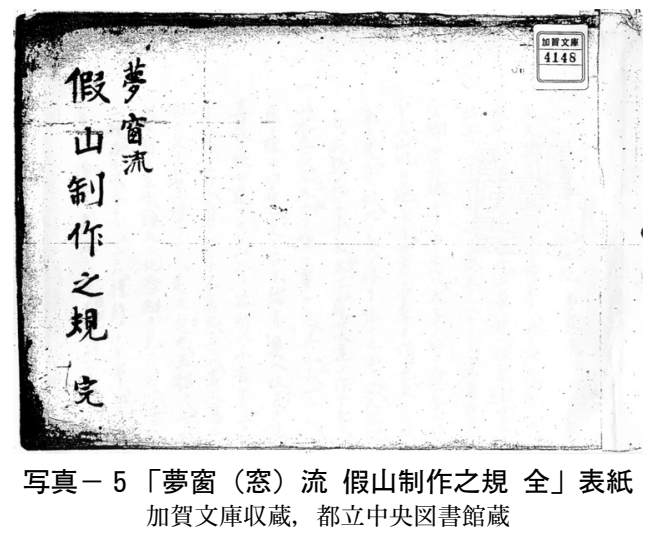

明治 44 年（1911）11月の跋文から，小澤が本冊子作成のため 校合・校訂に用いた書巻は，自蔵の「夢空国師築山秘書並圖」 1 冊, 「假山制作之規 夢窗流」一冊, 「庭坪築形傳書 山水夢想國師 傳」 1 冊, 並に東京帝国博物館所蔵「秘傳造庭巻」 1 冊であった。 上記にもあるように，これらは同一内容でしかも奥書に「應永二 年八月廿二日中院中納言康平寫之 文明七年三月七日四條權中将 藤為明前従從三位重範公ヨリ傳之寫之」との記述があることから, 各自が都合のよい題名つけたものに過ぎない。

同跋には，この「園書無名巻」と江戸時代の刊本園方書との関 係について次のように記している。「一略一然ルニ, 造園ノ方法 二, 眞, 行, 草, ノ區別 立テ, 又立石ノ方二拎テ, 二祥, 三吉, 三忌, 五禍ノ, 説, 並二律, 呂, 石ノ説 7 設定シ, 且又, 諸佛菩 薩ノ名ヨバ, 起石, 臥石, 等二配當シタリシ事ナド八, 顧フ二狡 獪ナル, 凡緇俗僧ノ手二テ編述セシヤ知ル可キナリ, 書末二, 夢 窗國師云云卜書キシ所有リ, 又奥書二, 應永二年, 八月廿二日, 中院中納言康平, 寫之卜有ル 二代, 若ク八三代ノ際二, 作成シタル者卜見ヘタリ, 蓋シ後世刊 本, , 築山山水傳, 築山庭造傳, 後篇築山庭造傳, 石組園生八重 垣傳等ノ諸書八皆此書 剽糫セシ事, 歴々トシテ之ヨ徵知ス可キ ナリ。」

また，同跋末尾には，「明治四十四年辛亥，十一月，東京府立 園藝學校，第三期生徒二，授讀ノ為メ二，鈔録下，蒝盟其 七十叟 小澤圭次郎識。」と記し, 本冊子は, 府立園芸学校の教材として 作成されたものであることを明示している。

本冊子には, 明治 28 年（1895）春の跋が掲載されていることか ら，明治 28 年には，本冊子はすでに作成されていたが，新たに， 明治 44 年（1911）11月の跋を末尾に加え完成させたこととなる。 小澤日記（東京都立園芸高等学校蔵）の同年 11 月 28 日には, 「早, 園芸校へ行, 無名巻園方書写修ス」と記述していることか ら，本冊子の完成は，具体的には 11 月 28 日となる。

\section{(4) 傳授系圖}

明治 44 年（1911）度講義最終日に解説した「伝授系図」とは, 園方書伝授の系図と園方書の記述内容がどう受け継がれたかをま
とめて系図としたものである。この系図には，印刷された 3 種類 と小澤の自筆系図との 4 種類がある。

印刷された系図は，明治 26 年（1892）「園苑源流考」に「園方 書傳來系圖 」36) として掲載され，『明治園芸史』所掲の「明治庭園 記」には「造園方法書傳統系圖」37) として，また，大正 15 年 （1926）頒布用につくられた謄写印刷の小冊子（写真－6）末尾 に「造園方法書傳統系圖」38) としてそれぞれ掲載されている。

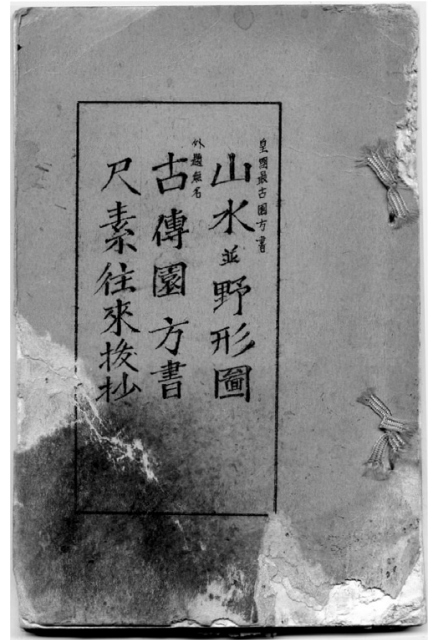

写真－６「山水並野形圖 古傳園方書 尺素往来跋抄」表紙 大正 15 年(1926) 4 月発行，東京都立園芸高等学校蔵

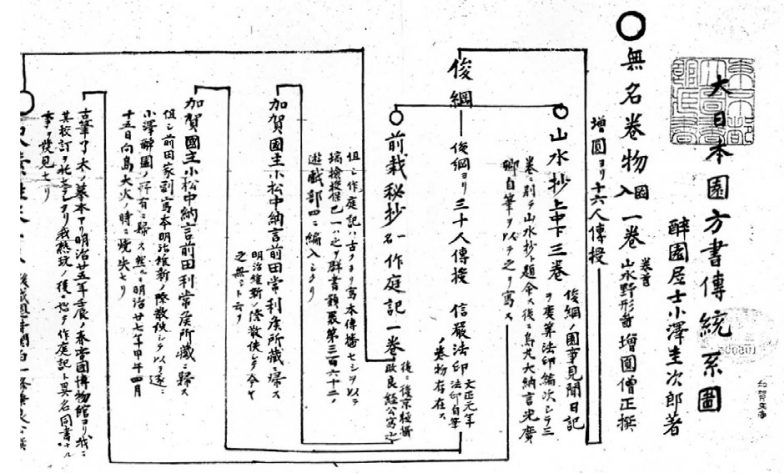

写真－７少澤圭次郎著「大日本園方書傳統系圖」冒頭部分 加賀文庫収蔵, 都立中央図書館蔵

また，手書きのものは，現在，東京都立中央図書館加賀文庫に 収蔵されている，小澤著「大日本園方書傳統系圖」 1 枚（写真一 7，1 尺 $\times 4.4$ 尺）である。これには，作成期日の記述がないの で，その時期を直接に知ることはできないが，「外題無名巻物 圖 入一巻 作者缺名 の項」に林旅所蔵の「箱書 山水庭石秘傳」（明 治 45 年夏購入）が，揭載されていることから，その制作時期は, 明治 45 年（1912）夏以前に遡ることはできない。

手書きの「大日本園方書傳統系圖」と印刷された前記 3 種系図 を比較すると，その題名に「傳統系圖」の名を用いていること， 記載内容が「明治庭園記」掲載の「造園方法書傳統系圖」に近い ものであること, 更に, 大正 3 年（1914）日記（東京都立園芸高 等学校蔵）の 8 月 30,31 両日に「園書系図习作ル」との記述が あることから, 本系図は,「明治庭園記」掲載のために, この時 期に制作されたものと考えることができる。

上記 4 種の制作時期から考えて，小澤が初年度講義最終日に説 明した「伝授系図」は，国華掲載の「園方書傳來系圖」にその後 の知見を加え，「明治庭園記」掲載の「造園方法書傳統系圖」に 近い内容のものであったと，推測できる。 


\section{5．小澤圭次郎の庭園観及び造園教育観}

小澤は, 造園研究のかたわら, 明治 44 年（1911）6月 21 日の 講義開始以来, 死去（昭和 7 年（1932）1月 12 日, 急性肺炎に て死亡） 前年の昭和 6 年（1931） 3 月まで 20 年間府立園芸学校 に於いて教鞭を執り続けた。小澤がこのような長期にわたって造 園教育に携わったのは, 自らの造園研究の過程で培った確固たる 庭園観，造園教育観がなければ，とうていなし得ない。このこと は, 磯村春夫（府立園芸学校大正 15 年卒）が証言している, 「俺 が死んだら日本庭園は闇だ」との小澤の発言 ${ }^{39)}$ からもわかる。小 澤の庭園観及び庭園教育観については，学校長鈴木の依頼によっ て設景した東京府立園芸学校園池の解説書『東京府立園藝學校園 池解説』の草稿の中に記されている。ここでは, この草稿をもと に，小澤の庭園観，造園教育観を明らかにする。

\section{（1）小澤圭次郎の庭園観}

「園林茶談」年) の中で，小澤は，我が国の造園の本質を，「元来， 山水庭は, 天然山海の景色を本として造り, 平庭は, 原野の風景 を形どるものである。」記し，更に「欧米諸國はいざ知らず， 我が國の造園は，自然を師とすれば足れりである。」と記してい る。

つまり，我が国の造園の本質は，自然を範とするもので，「山 水庭」のもとは, 自然の山や海の風景であり, 「平庭」のもとは, 原野の風景にあるということである。また，明治 44 年 (1911) 5 月 18 日，学校長鈴木の依頼による「日本庭園模範園」の解説書, 『東京府立園藝學校園池解説』の草稿 ${ }^{41}$ 「総論」の中で，造園の 方略（設景方法）は, 「山水」,「枯山水」, 「平地立石」の三種に 帰結するとして, 「造園の方略は, 多種多様にして, 窮極無しと 雖も, 古傳園方書に據りて, 之を大別すれば，則ち唯三種に帰す, 而して俗書の眞・行・草などいふ三區別は，毫も関係なしとす, 三種とは何そや，曰く山水，曰く枯山水，曰く平地立石，是なり， 山水とは，池を穿ち水を湛へ，山を築き石を立る者にて，後世の 築山泉水造の事なり, 枯山水とは, 池も無く, 遣水も無き處に, 石を立て山を築くの造方なり, 平地立石とは, 山も無く, 野筋も 無くて, 平地に石を立るものにて, 後世の平庭造の事なり」と記 している。

これら記述から, 古伝園方書研究を通じて, 小澤は, 我が国の 造園は, 自然を範とし, その設景方は, 山水 (築山泉水造), 枯 山水, 平地立石 (平庭造) の三種に帰結するとの明確な庭園観を 有していたことが，明らかとなる。

\section{（2）小澤圭次郎の造園教育観}

上記『東京府立園藝學校園池解説』の草稿の中で, 当時の造園 業界が，ただ経験に流れ，その技術の学芸研究を怠っているとし て,「従来植木職共の仲間の中にて, 少しく庭園経営の業に長せ し輩は，庭師と自称して，園池の設景を為し，又は其興造を擔仁 して，世人が林泉の需要に応じて，大小に幾多の庭園を作成せり， 其手腕に至りては，頗る巧妙を極めし者も多からずとせず，然れ ども，斯技術を学芸上に講演し得る者は，未た曾て一人も之有ざ るなり,」(1丁表）之痛烈に批判している。この現状に対し当校 の造園教育の目標は，学業と実際の庭園興造との一致に置くべき であるとして「抑も本校に於て, 第三学年の中に, 庭園の一科目 を設置せられたるは，斯学年間に在て，生徒をして庭園経営上の 学業を講習せしめ, 卒業後に之を実施する際に臨みて, 其学業を 事実と, 薑䔲するの処無からしめんが為めなる可し」(2丁表) と記している。更にこの目標達成のためには, 実際の庭を見, そ の景観構成, 各要素の配置を理解させる必要があるとして「故に 是非とも実地に就きて, 山之池との照応を始め，花木の按排，岩 石の布置より, 径路開通の縦横曲折, 橋梁架設の高低連絡に至る まで，一一之れが指示面諭を為し，随て是等品類の異状殊形に准 して, 景物の変化を生来し, 園趣の存没を転換すべき, 主旨要領 を講究会得せしむる事」(2丁裏) が必要であると強調している。 つまり，小澤は，造園教育の目的を，卒業後理論的裏付けをもっ て実際に庭を興造する能力を養うことに置き，この目的達成のた めに, 学業と同時に実物の庭での造園教育が欠かせないと主張し ているのである。

この主張こそ小澤の抱いた造園教育観に他ならない。小澤の庭 園観, 造園教育観に基づいて, 実際に設景されたのが, 東京府立 園芸学校園池であり，その具体的内容は，「東京府立園藝學校苑 池成景圖」（下書き，図-1) と「東京府立園藝學校園池指図」 （明治四十四年六月成 小澤手控，図－2）と，に反映されている。 この中で注目すべきことは, 平地立石 (平庭) 部分は, その場に ふさわしい草花植栽の実習場としても使用することを想定してい ることである (7丁裏)。理由は不明だが，小澤の設景した本園 池は，実際には作られることが無く幻に終わっている。明治 45 年（1912）から実施された，春秋 2 回の「庭園視察」では，小澤 は視察現場で各庭園について詳しく解説を行っている。これは, 小澤の学業と同時に実物の庭での教育が欠かせないとの教育観を 実践したためだといえよう。

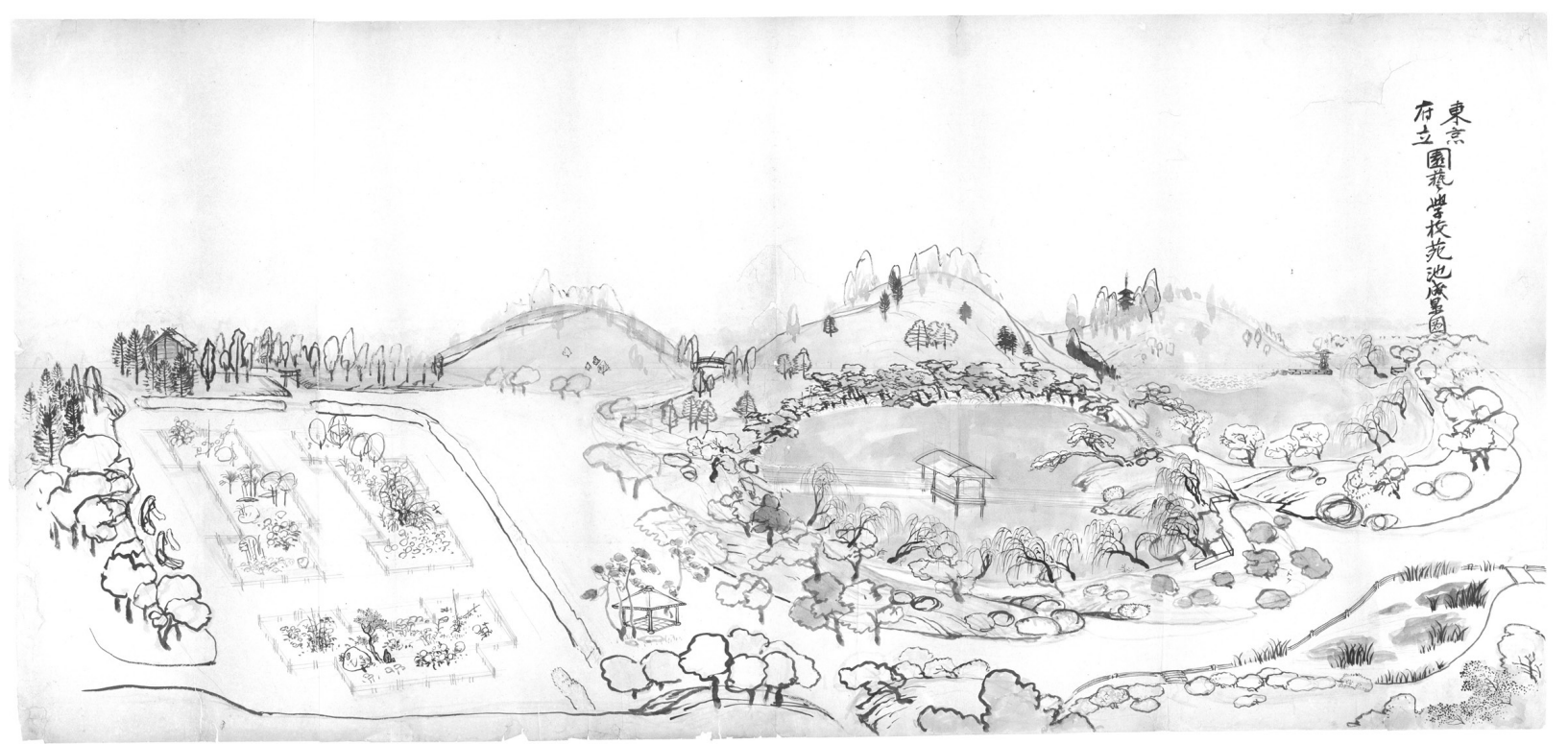

図－1 小澤自筆東京府立園芸学校苑池成景図＼cjkstart東京都立園芸高等学校蔵（原図サイズ $650 \times 1345 \mathrm{~mm} ）$ 


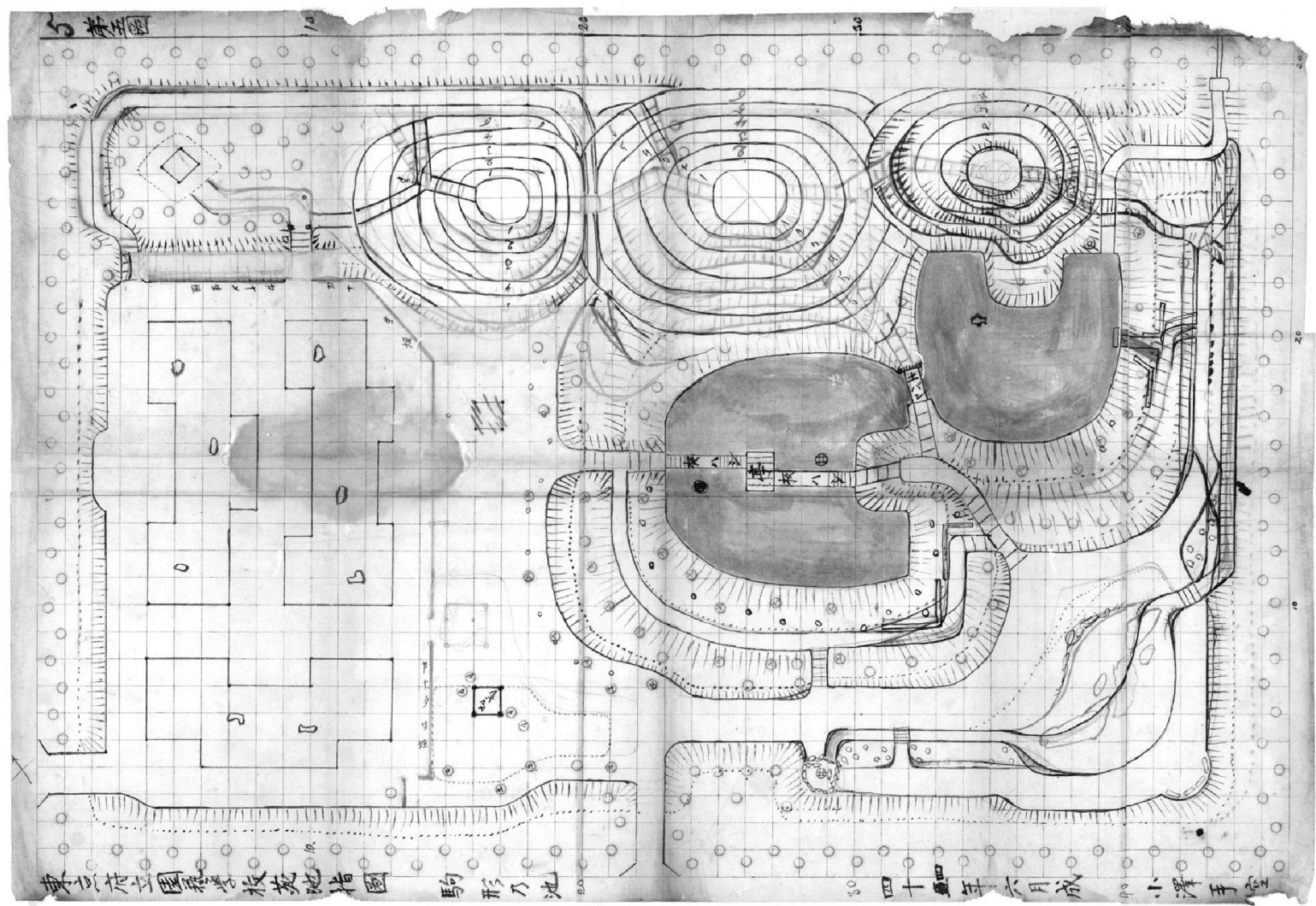

図－２小澤自筆東京府立園芸学校園池指図＼cjkstart東京都立園芸高等学校蔵（原図の縮尺 $1: 100$ グリッド幅 1 間で作図，原図サイズ $595 \times 865 \mathrm{mm）}$

\section{6. まとめ}

明治 41 年（1908）4 月開校の東京府立園芸学校に於いて学科 目「園芸」の教育内容の一つとして,「庭園」が教育課程に明記 された。これが我が国の農業学校に於いてその教育課程に造園教 育が位置づけられた始まりである。この講師として，二代学校長 鈴木武太郎は，当時最も著名な造園家小澤圭次郎（醉園）を招聘 した。小澤は，この「庭園」講義を明治 44 年（1911）6 月 21 日 午前 9 時に開始し，自ら校合・校訂して作成した「前栽秘抄」 (作庭記), 「最古園方書」(山水并野形図), 「園書無名巻」(嵣峨 流古法秘伝之書）の古伝園方書を教材として, 一年間 12 回庭園 教育を行った。

教材として, 古伝園方書を用いたのは, 自己の造園研究を通じ て, 我が国の造園方法を正しく理解するには, 古伝園方書の理解 こそが必要であると確信していたからである。この姿勢は, 講義 開始以来, その職を辞するまで変わることは無かった。また, 講 師招聘之同時に, 学校長鈴木からの依頼により, 当校の園池設景 を託される。小澤はこの園池を, 自らの庭園観及び造園教育観を 現実しようとの意図で設景を行ったが，この設景は，その実現を 見ることはなかった。

小澤は, 農業学校での造園教育の草創期から死の前年まで，そ の晚年を自己の造園研究と同時に, 毎月 1 回東京府立園芸学校で の講義に 20 年間変わる事無く情熱を注いでいる, これは, 先に 引用した教え子磯村春夫の証言にある「俺が死んだら日本庭園は 闇だ」との小澤の強い自負と強固な信念あったからだといえよう。

\section{補注及び引用文献}

1 ）横井時敬（1905）：園芸學校設立の必要：日本園芸会雑誌第 157 号, $1-7$

2 ) 明治 42 年（1909） 3 月 25 日, 大阪府立農学校学則, 大阪府令第 38 号第 3 章掲載の課程授業時数表に, 学科目「園芸」第 3 年級 5 時間履
修の教育内容, 具体的には果樹, 促成温室, 庭園, 盆栽の一つに「庭 園」が設定されている。

3 ) 千葉県立園芸専門学校学則第 3 章第 7 条学科課程表, 明治 43 年 5 月 31 日, 千葉県令第 49 号

4 ）上原敬二（1983）：この目で見た造園発達史：この目で見た造園発達 史刊行会, 51p

5 ) 東京府立園芸学校学則第 9 条掲載教育課程及毎週教授時数, 明治 41 年（1908） 3 月 12 日，東京府令第 27 号

6 ）宮澤文吾（1884-1968）明治 43 年 7 月東京帝国大学農科大学農学科卒。 卒業後すぐ，東京府立園芸学校教諭に就任。東京府立園芸学校教諭在 任期間は，明治 43 年（1910）８月 6 日から大正元年（1912）12 月 16 日神奈川県農事試験場技師へ転任まで。

7 ）宮澤文吾の次女，宮澤スミエ氏は，東京府立園芸学校教諭在任時期の 記録の有無についての筆者の問い合わせに対して，筆者宛手紙（平成 19 年（2007）11月 8 日付）の中で「昔の日記の類は，大正 12 年関東 大震災の時，横浜にて全焼し，大正 12 年以前のものをすへて失いま した。」記されている。

8 ）西村公宏（1991）：札幌農学校におけるランドスケープガーデニング, 造園雑誌 54(5)，37-42

9 ）小林治人（1995）：醉園小澤圭次郎 伝統庭園庇護・継承に生きた 「設景家」，ランドスケープ研究 58(3)，245

10）吉川需（1994）：圭次郎(酔園)の詩学研鑽，庭園復刊第 5 号，16-18

11）小林治人（1995）：醉園小澤圭次郎 伝統庭園庇護・継承に生きた 「設景家」，ランドスケープ研究 58(3)，246

12）小澤圭次郎（1911）：庭園に就て：日本園芸雜誌第 234 号，30-31

13）上原敬二（1979）：談話室の造園学：技法堂出版, 31p.

14）小澤圭次郎（1890）：園苑源流考：国華第 5 号, 2

15）上原敬二（1979）：談話室の造園学：技法堂出版, $32 \mathrm{p}$

16）福羽逸人述，林旅筆記（1976）：園藝論：日本公園緑地協会，56p.

17）東京都立園芸高等学校同空会編（1978）：東園の七十年：東京都立園 芸高等学校同空会：34-35p. なお，本引用文中にある庭園視察は，小 
澤日記（大正十四年酔園日誌，東京都立園芸高等学校蔵）によれば, 大正 14 年 (1925）5月 6 日（水）に実施された。

18）鈴木武太郎（1869-没年不詳, 明治 25 年東京帝国大学農科大学農学科 卒, 農商務省勤務, 軍務, 山口県立農業学校長を経て, 明治 42 年 （1909）８月 1 日東京府立園芸学校第二代学校長に就任, 大正 6 年 （1917）5月 19 日東京府立農林学校長に転出。

19）小澤圭次郎（1911）：庭園に就て：日本園芸雜誌第 234 号，30-31

20）明治 44 年（1911） 4 月 27 日の東京府立園芸学校の創立記念日の講演 は, 宮澤文吾によって筆記され, 小澤の校正をへて「日本古代の造園 書に就て」として「日本園芸雜誌」に掲載されている。(小澤圭次郎 （1911）：日本古代の造園書に就て：日本園芸雑誌第 225 号，1-6）こ の講演会について小澤は日記 (四十四日記, 東京都立園芸高等学校蔵) に次のように記している。「甘七日 陰, 早起, 六半出, 八時至駒澤, 迎人輩来在, 即東京府立園芸学校へ行, 鈴木校長室二入対語, 九時半 講堂二出, 学生百四十餘名列座, 我日本最古造園方書, 殊作庭記後京 極提政作ニ非サル旨説明ス, 十時半過了校長室二退キ午餐习受ク, 校 長同食, 教諭宮澤文吾草記ス我書写ヨ校正スルヨ約ス, 報酬受, 二時 校ᄏ退ク，五時帰宅。」(句読点は，筆者）

また， 日本園芸会夏期講習会での講演は，本講習会初日，明治 44 年（1911）8月 15 日午後に「白須甲斐守の別荘新修の時の空前名案 及小石川植物園並砲兵工廠内後楽園の歴史」と題して約 2 時間の講演 を行ったと記録されている。また，本講集会六日目 8 月 20 日には,

千葉県立園芸専門学校長鏡保之助による講演「日本庭園の特質及其変 遷」もなされている。（日本園芸雑誌第 228 号，63-64）。小澤のこの 日の日記(四十四年日記, 東京都立園芸高等学校蔵)には, 「十五日 朝三時ヨリ草稿着手, 白須荘草稿直, 浄写, 早午, 早稲田大学講堂へ 行, 園芸会夏期講習会, 白須別荘講話ス。」(句読点は, 筆者) と記し ている。

21）鈴木が東京府に提出した上申書（明治 44 年, 第 1 類・文書類纂・学 事第 9 類・府立学校職員第 3 巻収蔵, 東京都公文書館蔵）の記載は, 次の通りである。

$$
\begin{array}{r}
\text { 嘱託教員任命八儀上申 } \\
\text { 東京府平民 }
\end{array}
$$

\section{小澤圭次郎}

右者庭園二関スル授業 $\ni$ 嘱託致度二付御任命ノ上年手

當金百円給與与相成度別紙履歴書相添此段上申候也

明治四十四年六月八日

$$
\text { 東京府立園藝學校長鈴木武太郎 印 }
$$

\section{東京府知事阿部浩殿}

追テ五月三十一日付 $コ$ 以テ任命相成度候

$22 ）$ 熊谷八十三, 明治 33 年（1900）東京帝国大学農科大学農学科卒, 府 立園芸学校長在任期間は, 愛知県立農林学校教諭から転じて, 明治 41 年（1908） 2 月 23 日初代学校長に就任から, 明治 42 年（1909） 7 月 末農商務省農事試験場興津園芸部技師に転出まで。

23）宮地常助（1894-1978）, 大正 12 年（1923）東京帝国大学農学科卒, 府立園芸学校教諭在任期間は大正 12 年 4 月から昭和 11 年 (1936) 6 月都市計画北海道地方委員会技師転出まで。

24）東京都立園芸学校同空会編（1978）：東園の七十年 : 東京都立園芸高 等学校同空会 : 33

25）小澤の講義回数については, 東京府立園芸学校講師在任期間の明治 44 年（1911）から昭和 6 年（1931）まで間の現存する日記（昭和 4 年 $(1929)$ と 6 年 (1931) を除く, 東京都立園芸高等学校蔵) の記述 を確認した結果，一年 12 回であった。

26）鈴木の明治 44 （1911）年 6 月 13 日付け小澤宛書簡(東京都立園芸高 等学校蔵)の全文は以下に示す通りである。

二伸，先般ご送付致し辞令書八手続上の錯誤有之候に付今回添送の 分と御交換被下度候也

拝啓, 先般来設計書御調製に付御謜精の段ご苦労に奉存候。又此程 御申越の庭園講義の件に付テ八当方に於て夫の時間の都合相考申候処, 水曜日の午前九時より十一時まての二時間に相願度本月二十一日か廿
八日の何れにても貴方のご都合次第御決定の上御一報相願度, 尤も原 稿は謄写版印刷の都合も有之候へ八，可相成は一週間位以前に御送付 相願度候次に設計書は小生罷出, 受領可致心得に候へ共或は用事の為 め差支, 使の者を差遣可致や屯計られす候えは此儀ご了承被下度大体 何日頃, 罷出候て宜敷やは折返へし御一報被下度候

不取敢右御問合はせまて。草々敬具

$$
\text { 六月十三日 }
$$

武太郎

小澤老臺

玉机下

27）小澤圭次郎（1911）：庭園に就て：日本園芸雜誌第 234 号，31

28）ここに記した小澤日記（東京都立園芸高等学校蔵）各日の記述は次の 通りである。

- 明治 44 年(1911) 6 月 21 日（水） 陰, 四時起六時出, 本朝ヨリ無事 出校, 九時ヨリ十時迄講堂二テ前栽秘抄十枚斗話説

- 同年 9 月 20 日（水）最古園方書, 序咙成, 浄写又

・同年 9 月 21 日（木）早出, 駒沢校へ行, 園方書出,

- 同年 11 月 25 日（土）園書無名卷画図写又,

- 同年 11 月 28 日 (火) 早, 園芸校へ行, 無名巻園方書写修ス,

- 同年 12 月 6 日（水）四時起六過, 無事園芸校へ行, 九時ヨリ二時 間講義増圓哲書了, 后一時退校,

- 明治 45 年 (1912) 3 月 6 日（水）昨日来雨, 四時起七時半出, 園 芸学校へ行, 昨来六日迄本講義古伝園方書了, 伝授系図講説又

29）小澤圭次郎（1911）：日本古代の造園書に就て：日本園芸雑誌第 225 号, 1-6

30）小澤圭次郎（1893）：園苑源流考：国華第 42 号，116

31）小澤圭次郎（1915）：明治庭園記：明治園芸史：日本園芸研究会, 303

32）小澤圭次郎校 - 手写：山水抄三巻, 東京都立中央図書館加賀文庫収蔵

33）山水抄三巻の校訂についての, 小澤日記（明治 25 年日記, 東京都立 園芸高等学校蔵）の記述は次の通りである。

・明治 25 年(1982) 1 月 27 日（木）后博物館使来，川崎千质ヨリ山水 抄

一冊，山高命ニヨリ送来ル，一読，甚読カタシ，作庭記二比較スレ 八同書ナリ，体裁ヨ異ニスル

- 同 1 月 28 日（金）山水抄浄写, 夜亦然, 昨午後ヨリ三十枚二至ル

• 同 1 月 30 日（土）山水抄写成，校訂加朱二取捗ル

・同1月 31 日（日）山水抄作庭記著者弁妄 7 写又

・同 2 月 1 日 (月) 川崎へ山水抄 7 返却又

- 同 2 月 2 日 (火) 朝, 山水抄跋 7 書又

・同 2 月 4 日（木）山水抄校訂了

34）「増圓僧正撰 皇國最古園方書 全」の校合の経緯に関する，小澤日記 (明治 25 年日記, 東京都立園芸高等学校蔵) の記述は次の通りである。 - 明治 25 年（1892）1月 29 日（金）加州邸野口之布 Э訪, 不在也, 斎藤書肆へ寄, 野口へ一書 $\ni$ 托又,

- 同 2 月 8 日（月）前, 本郷加州邸野口之布 7 訪フ, 山水并野形古写 本卜有ル, 仁和寺心蓮院蔵印アリ, 我蔵八此写ナリ,

- 同 3 月 14 日（月）本郷前田邸野口之布 7 訪フ, 増圓撰園書校訂 為又,

35）小澤圭次郎（1893）：園苑源流考：國華第 48-50 号

36）小澤圭次郎（1892）：園苑源流考，國華第 50 号，35-38

37）小澤圭次郎（1915）：明治庭園記：明治園芸史：日本園芸研究会, 467-472

38）小澤圭次郎編（1925）：山水並野形圖 古傳園方書 尺素往来跋抄：自 費出版, 111-114

39）東京都立園芸高等学校同空会編（1978）：東園の七十年：東京都立園 芸高等学校同空会, 35

40）小澤圭次郎（1906）：日本園芸雑誌第 159 号， 58

41）小澤圭次郎自筆（1911）：東京府立園藝學校園池解説草稿，33 丁 (東京都立園芸高等学校蔵)

(2008.9.30 受付, 2009.5.9 受理) 